\title{
Period of time taken by Brachiaria humidicola (Rendle) Scheweick seed to complete germination
}

\author{
Duração do teste de germinação de sementes de Brachiaria \\ humidicola (Rendle) Schweick
}

\author{
Camila de Aquino Tomaz ${ }^{1}$; Cibele Chalita Martins ${ }^{2 *}$; \\ Givanildo Zildo da Silva ${ }^{3}$; Roberval Daiton Vieira ${ }^{4}$
}

\begin{abstract}
The period of 21 days suggested by the Brazilian Rules for Seed Testing for the germination test of $B$. humidicola seeds seems too long for seed producing companies and laboratories since they depend on the results for decisions concerning the storage or the commercialization of the seed lots. So, the objective of this work was to evaluate the possibility of getting germination results of B. humidicola seeds in a shorter period. The procedures consisted in submitting the seeds to a dormancy breaking treatment and to alternating temperatures during the germination test. Seed samples of nineteen S1 and S2 seed lots were submitted to the following treatments: moistening the germination substratum with 1) deionized water (check treatment), 2) a $\mathrm{KNO}_{3}(0.2 \%)$ solution, and 3) scarifying the seeds with sulfuric acid for 10 minutes. The germination test was conducted under the conditions of 1) alternating temperatures of 20 and $35^{\circ} \mathrm{C}$ and 2) alternating temperatures of 15 and $35^{\circ} \mathrm{C}$ both with 8 hours of light. Normal seedlings were evaluated in daily countings. The results showed that the germination test of $B$. humidicola seeds may be carried out under alternating temperatures of 15 and $35^{\circ} \mathrm{C}$ without breaking seed dormancy with a final evaluation of the germination 10 days after the sowing of the seeds.
\end{abstract}

Key words: Dormancy. Forage grass. Pasture. Temperature.

\section{Resumo}

O período de 21 dias recomendado pelas Regras para Análise de Sementes para o teste de germinação de sementes de $B$. humidicola é considerado excessivo por produtores, comerciantes e laboratórios de análise de sementes, que dependem dos resultados do teste para o controle de qualidade e a comercialização. Desta forma, o objetivo do trabalho foi avaliar a possibilidade de reduzir o período necessário para a condução do teste de germinação de sementes de $B$. humidicola, estabelecendo o método para superação da dormência e a temperatura ideal. Dezenove lotes de sementes comerciais S1 e S2 recém-recebidos na unidade de beneficiamento foram avaliados quanto à germinação, em quatro subamostras de 100 sementes por tratamento, constituído de: substrato umedecido com água deionizada (testemunha), substrato umedecido com $\mathrm{KNO}_{3}(0,2 \%)$ e escarificação com ácido sulfúrico por 10 minutos. Para o teste de germinação, foram avaliadas duas condições de temperaturas alternadas (20-

\footnotetext{
${ }^{1}$ Bolsista Pós-doutorado Faculdade de Ciências Agronômicas, Universidade Estadual Paulista Júlio de Mesquita Filho, FCA/ UNESP, Botucatu, SP, Brasil. E-mail: caatomaz@hotmail.com

${ }^{2}$ Prof $^{\mathrm{a}} \mathrm{Dr}^{\mathrm{a}}$, Dept ${ }^{\mathrm{o}}$ de Produção Vegetal, Faculdade de Ciências Agrárias e Veterinárias, Universidade Estadual Paulista Júlio de Mesquita Filho, FCAV/UNESP, Jaboticabal, SP, Brasil. E-mail: cibele@fcav.unesp.br

${ }^{3}$ Discente de Doutorado do Programa de Pós-graduação em Agronomia, Faculdade de Ciências Agrárias e Veterinárias, Universidade Estadual Paulista Júlio de Mesquita Filho, FCAV/UNESP, Jaboticabal, SP, Brasil. E-mail: givanildozildo@hotmail.com

${ }^{4}$ Prof. Dr., Dept ${ }^{\circ}$ de Produção Vegetal, Faculdade de Ciências Agrárias e Veterinárias, Universidade Estadual Paulista Júlio de Mesquita Filho, FCAV/UNESP, Jaboticabal, SP, Brasil. E-mail: rdvieira@fcav.unesp.br

* Author for correspondence
} 
$35^{\circ} \mathrm{C}$ e $\left.15-35^{\circ} \mathrm{C}\right)$, com luz (8h). Para definição do período do teste, foram realizadas contagens diárias de plântulas normais e, para cada tratamento, foram ajustadas curvas para avaliação da germinação. No delineamento experimental, os lotes foram considerados as repetições, obtendo-se as estimativas dos parâmetros do modelo de regressão segmentada para cada tratamento. $\mathrm{O}$ teste de germinação de sementes de $B$. humidicola pode ser conduzido a $15-35^{\circ} \mathrm{C}$, sem tratamento para a superação da dormência, com avaliação final aos 10 dias após a semeadura.

Palavras-chave: Dormência. Gramínea forrageira. Pastagem. Temperatura.

\section{Introduction}

Brazil is the largest producer and exporter of tropical pasture grass seeds, with a total production of approximately 100 thousand tons of pure, viable seed per year. Circa $20 \%$ of that total is exported to South and Central America, Africa and the United States. Pasture seeds are estimated to represent a market of around 600 million dollars per year (VERZIGNASSI, 2013).

Evaluating seed germination is a key point in quality control programs since it is mandatory for the approval of the lots for the national and international commercialization of seeds (BRASIL, 2009; GASPAR-OLIVEIRA et al., 2008; ISTA, 2009; TOMAZ et al., 2015).

According to the Brazilian as well as the International Rules for Testing Seeds (BRASIL, 2009; ISTA, 2009), the period of time demanded by seeds of the Brachiaria genus is of 21 days which may be extended to 28 days when dormant seeds are to be considered. Seed analyzers, seed producers, and farmers consider this to be a long period.

The present recommendations for the germination test of Brachiaria humidicola seeds are not different from those first published in the 1980 decade (BRASIL, 1980; ISTA, 1985), when the grass seed production sector made use of less costly and efficient technologies. Developments experienced in this market have made possible the production of grass seed lots of higher germination in terms of speed and uniformity of germination (VERZIGNASSI, 2013).

Norms and procedures of the Rules for Testing Seeds are periodically revised by a committee formed by researchers and other professionals. Replacing procedures must be based on research results.

Research results obtained in the last decade with Brachiaria brizantha (Hochst ex A. Rich) and Brachiaria decumbens Stapf. seeds showed that the duration of the germination test may be reduced to half that period, or more (GASPAR-OLIVEIRA et al., 2008; TOMAZ et al., 2015). This is expected to occur with $B$. humidicola seeds too. This is a species though demanding special additional studies searching for procedures to make possible the reduction of the period of time demanded by the germination test.

The temperature for the germination test and the recommended procedure for overcoming seed dormancy, as indicated by the Rules for Testing Seeds, may cause doubts and thus influence the results. For Brachiaria seeds, the indicated temperatures for the germination test are of 20$35{ }^{\circ} \mathrm{C}$ and $15-35^{\circ} \mathrm{C}$ (BRASIL, 2009). The first condition is also indicated by the International Rules for Testing Seeds (ISTA, 2009).

In addition to indicating alternating temperatures for the germination test of grass seeds, the Brazilian and the International Rules for Testing Seeds also make recommendations for the overcoming of seed dormancy which include seed scarification with concentrated $\mathrm{H}_{2} \mathrm{SO}_{4}$ and/or moistening the substratum with a $\mathrm{KNO}_{3}$ solution at $0.2 \%$. For Brachiara brizantha seed pre drying for 5 to 7 days at temperatures between 35 and $40{ }^{\circ} \mathrm{C}$ in forced ventilation ovens is recommended (BRASIL, 2009; ISTA, 2009). Results, depending on the species and seed lot, may be favorable, harmful, or null 
(BRITES et al., 2011; CAVALCANTE FILHO; USBERTI, 2008; GASPAR-OLIVEIRA et al., 2008; MARTINS; MARTINS, 2013; MARTINS et al., 2013; TOMAZ et al., 2015; USBERTI; MARTINS, 2007).

Thus, the objective of this project was to evaluate the possibility of reducing the period of time necessary for the germination test of Brachiaria humidicola, the method for seed dormancy overcoming, and the ideal temperature.

\section{Material and Methods}

This project was developed at the Seed Analysis Laboratory, a unit of the Plant Production Department of the UNESP (Paulista State University) campus of Botucatu, state of São Paulo. S1 and S2 (first and second generations of basic seeds, respectively) seeds from 19 commercial lots of different origins were taken at the reception point of the seed producing company and then submitted to cleaning in screens and a pneumatic blower. This was followed by manual cleaning so as to get pure seeds. These seeds were submitted to the following determinations.

Seed water content - evaluated by the oven method and thus submitted to an air temperature of $105 \pm 3{ }^{\circ} \mathrm{C}$ for 24 hours (BRASIL, 2009), each lot represented by two $2.0 \mathrm{~g}$ samples. The acid scarified seeds also had their water content determined.

Germination test - four 100 seed samples from each lot were taken for the germination test. In plastic boxes $(11.0 \times 11.0 \times 3.0 \mathrm{~cm})$ (BRASIL, 2009; ISTA, 2009), the seeds were sown on two sheets of filter paper to which deionized water at an amount 2.0 times the weight of the paper was added. The boxes were placed inside plastic bags to reduce substratum dehydration (GASPAR-OLIVEIRA et al., 2007). The resulting seedlings were considered normal when the plumule had protruded above the coleoptile and the primary root was at least $0.5 \mathrm{~cm}$ long. Daily counts were made up to 21 days after the installation of the test with an additional period of seven days to be in accordance to the Rules for Testing Seeds (national and international (BRASIL, 2009; ISTA, 2009).

The germination test was conducted under two temperature conditions, that is, $15-35{ }^{\circ} \mathrm{C}$ for $16-8$ hours and $20-35^{\circ} \mathrm{C}$ for $16-8$ hours and a photoperiod of 8 hours of light and submitted (or not, in the check treatment) to the following dormancy overcoming treatments: substratum wetting with a $0.2 \% \mathrm{KNO}_{3}$ solution, seed scarification with a $\mathrm{H}_{2} \mathrm{SO}_{4}(98 \% 36$ N) P.A. solution for 10 minutes followed by washing in running water for five minutes and drying under room conditions (BRASIL, 2009; ISTA, 2009).

At the end of the germination test, the seeds remaining intact were tested to verify whether they were dormant or dead by means of the tetrazolium test. Those seed were longitudinally and medium sectioned through the embryo and one of the halves was immersed in a $0.075 \%$ tetrazolium solution in a dark chamber at a temperature of $40{ }^{\circ} \mathrm{C}$ for 2 hours. After that, the seeds were washed and the evaluation made immediately; the seeds were considered either viable (dormant) or non-viable (dead) (NOVEMBRE et al., 2006).

The treatments were distributed according to a randomized complete block design in a factorial scheme $3 \times 2$ (dormancy breaking treatments $\mathrm{x}$ germination temperatures). Each replication was constituted of the 19 commercial lots and for each treatment a growth curve was adapted using the non-linear model for the evaluation of germination percentage. This model permitted the determination of the period of time necessary for the conduction of the test by calculating the value from which the difference between the asymptote and the estimated function was not statistically significant (SALLUM NETO et al., 2013).

The adjustment of the curves used the model $y$ $=\mathrm{a} /\left(1+\exp \left(-\mathrm{b}+\mathrm{c}^{*} \mathrm{x}\right)\right.$ where " $a$ " is the asymptote, representing the percentage of germination, " $b$ " is the position parameter, representing the curve 
dislocation, "c" is related to the speed of germination and " $\mathrm{x}$ " represents the period of time necessary for conducting the test. The used regression model was of the type:

$$
\mathrm{Y} 1=\mathrm{L}+\mathrm{U}(\mathrm{R}-\mathrm{XLRi})+\mathrm{ei}, \mathrm{I}=1,2, \ldots \mathrm{ni}, \mathrm{ni}+
$$
1 ... $n$; whose $(\mathrm{R}+\mathrm{XLRi})=0$ for $\mathrm{i} \geq \mathrm{ni}+1$ and $\mathrm{n} 1$ is the number of observations where Yi represents the germination percentage, $\mathrm{L}$ the point of maximum germination, $\mathrm{U}$ the coefficient of determination, $\mathrm{R}$ the date of stabilization, XLRi the period of time (days), and "ei" the random component or residue.

\section{Results and Discussion}

The result of the germination test of $B$. humidicola seeds showed that only temperature influenced the final percentage of germination (Table 1). None of the evaluated methods for overcoming dormancy changed the germination stabilization date and the speed of germination.

Table 1. F values and significance of estimated values of germination percentage (G), germination stabilization date (GSD), and speed of germination (SG) of B. humidicola seeds.

\begin{tabular}{lccc}
\hline Source of variation & G & GSD & SG \\
\hline Overcoming of seed dormancy & $0,04 \mathrm{~ns}$ & $1,07 \mathrm{~ns}$ & $2,33 \mathrm{~ns}$ \\
Temperature & $4,29^{*}$ & $1,61 \mathrm{~ns}$ & $0,37 \mathrm{~ns}$ \\
Overcoming of seed dormancy x Temperature & $0,69 \mathrm{~ns}$ & $0,27 \mathrm{~ns}$ & $0,65 \mathrm{~ns}$ \\
\hline
\end{tabular}

*, ns: significant at 5\% and non-significant according the $\mathrm{F}$ test, respectively.

The non-significant values shown by all parameters after the seeds were submitted to the overcoming of dormancy (Table 1) permitted the conclusion that the mean largest water content of the $\mathrm{H}_{2} \mathrm{SO}_{4}$ scarified seeds $(12.2 \%)$ in comparison with non-scarified (7.8\%) (Table 2 ) did not influence either the speed of the process or the final result of the germination test.

Seed water content is the most important factor for the standardization of the evaluations to be made. It is recommended that samples to be compared do not show water content differences that may lead to biased results due to its influence on seed absorption of water during the germination test (MARCOS FILHO, 2005).

The higher hydration shown by the scarified seeds was due to the fact that that operation brought about the rupture of the physical barrier formed by the glumes and glumeles thus making easier the entrance of water in the seeds since, after being washed, the seeds were spread out over paper towel under room conditions for two hours. This period of time was sufficient for the absorption of water. Similar results were reported by Gaspar-Oliveira et al. (2008) in a research work with B. brizantha cv. Marandu.

The highest germination percentages shown by the $B$. humidicola seeds were observed to occur when the alternating temperatures of $15-35{ }^{\circ} \mathrm{C}$ were used independently of the dormancy breaking treatment applied (Table 3). Under those temperatures, seed mean germination was of $74 \%$, superior to the $68 \%$ obtained when the alternating temperatures were of 20-35 ${ }^{\circ} \mathrm{C}$. Similar results were reported by Oliveira and Mastrocola (1984) in a research work with $B$. humidicola - the best result was attained when the alternating temperatures of 15 and $35^{\circ} \mathrm{C}$ were used. 
Table 2. B. humidicola seeds water content before and after scarification with $\mathrm{H}_{2} \mathrm{SO}_{4}$.

\begin{tabular}{ccc}
\hline \multirow{2}{*}{ Lots } & \multicolumn{3}{c}{ Seed water content $(\%)$} \\
\cline { 2 - 3 } & Before & ${\text { After } \mathrm{H}_{2} \mathrm{SO}_{4}}$ \\
\hline 1 & 7,6 & 12,6 \\
3 & 7,4 & 11,7 \\
4 & 8,1 & 11,9 \\
5 & 8,0 & 11,7 \\
6 & 8,1 & 11,9 \\
7 & 7,5 & 11,8 \\
8 & 7,9 & 12,1 \\
9 & 8,2 & 12,2 \\
10 & 8,1 & 12,3 \\
11 & 7,9 & 12,2 \\
12 & 8,1 & 12,2 \\
13 & 8,0 & 11,8 \\
14 & 8,0 & 11,9 \\
15 & 7,7 & 12,4 \\
16 & 8,1 & 12,9 \\
17 & 7,4 & 12,7 \\
18 & 7,9 & 12,9 \\
19 & 7,8 & 12,8 \\
Mean & 7,6 & 12,6 \\
\hline
\end{tabular}

Table 3. Mean and standard deviation of the estimation of B. humidicola seed germination as influenced by treatments for overcoming seed dormancy and temperature.

\begin{tabular}{lccc}
\hline \multirow{2}{*}{ Treatments for overcoming seed dormancy } & \multicolumn{2}{c}{ Temperature $\left({ }^{\circ} \mathrm{C}\right)$} & \multirow{2}{*}{ Mean } \\
\cline { 2 - 3 } & $15-35$ & $20-35$ & $71 \pm 15$ \\
Check treatment & $76 \pm 11$ & $66 \pm 18$ & $70 \pm 16$ \\
$\mathrm{KNO}_{3}$ & $71 \pm 15$ & $70 \pm 17$ & $71 \pm 14$ \\
$\mathrm{H}_{2} \mathrm{SO}_{4}$ & $75 \pm 11$ & $67 \pm 16$ & \\
\hline Mean & $74 \pm 12 \mathrm{a}$ & $68 \pm 17 \mathrm{~b}$ & \\
\hline
\end{tabular}

Means in the same line followed by the same letter are not statistically different at the $5 \%$ level of probability, according to Tukey's test.

The optimal temperature for the germination of seeds varies with species and the seed lot physiological quality. Carneiro et al. (1986) verified that the alternating temperatures of 20-35 ${ }^{\circ} \mathrm{C}$ favored the germination of $B$. humidicola in comparison with the alternating temperatures of 20$30{ }^{\circ} \mathrm{C}$ and the constant of $30^{\circ} \mathrm{C}$. On the other hand, Gaspar-Oliveira et al. (2008) reported that both the temperature regimes of $15-35{ }^{\circ} \mathrm{C}$ and of $20-35{ }^{\circ} \mathrm{C}$ led $B$. brizantha seeds to maximum and similar germinations.
B. humidicola seeds germination showed relatively high values for the species, that is, around $70 \%$, independently of the treatment to them applied (Table 3), so within the limits established by the Instruction Norm 30, dating of May 21, 2008, that is a minimum germination of $40 \%$ (BRASIL, 2008). A study using 92 samples of $B$. humidicola showed that the mean germination was between 35 and $40{ }^{\circ} \mathrm{C}$ (USBERTI; MARTINS, 2007) and this was considered as an indication of the improvement attained in forage seed quality in the preceding 
decade. This evolution, associated with the treatments used in this experiment, made possible germination values superior to $60 \%$ (Table 3 ).

Another indication of the improvement shown by the sector was the fact that the treatments viewing the breaking of seed dormancy were not effective (Table 3) and that they also did not affect speed of germination or the date for germination stabilization (Table 1), showing that the seed lots showed no dormancy. The tetrazolium test conducted at the end of the germination test showed that the remaining non-germinated seeds were dead, and not dormant.
Dormancy in pasture seeds is undesirable since it leads to reduced seedling emergence in the field and the establishment of the pasture (CAVALCANTE FILHO; USBERTI, 2008; COSTA et al., 2011; VERZIGNASSI, 2013).

Speed of germination and the final counting date of the germination test were not affected by the treatments for seed dormancy overcoming and temperature regimes as shown by the nonsignificant values of the parameters shown in Table 1 and by the similarity between the curves as to their inclination (Figure 1).

Figure 1. Germination stabilization point of 19 B. humidicola seed lots submitted to different seed overcoming methods and germination at the alternating temperatures of $15-35^{\circ} \mathrm{C}$ and $20-35^{\circ} \mathrm{C}$.
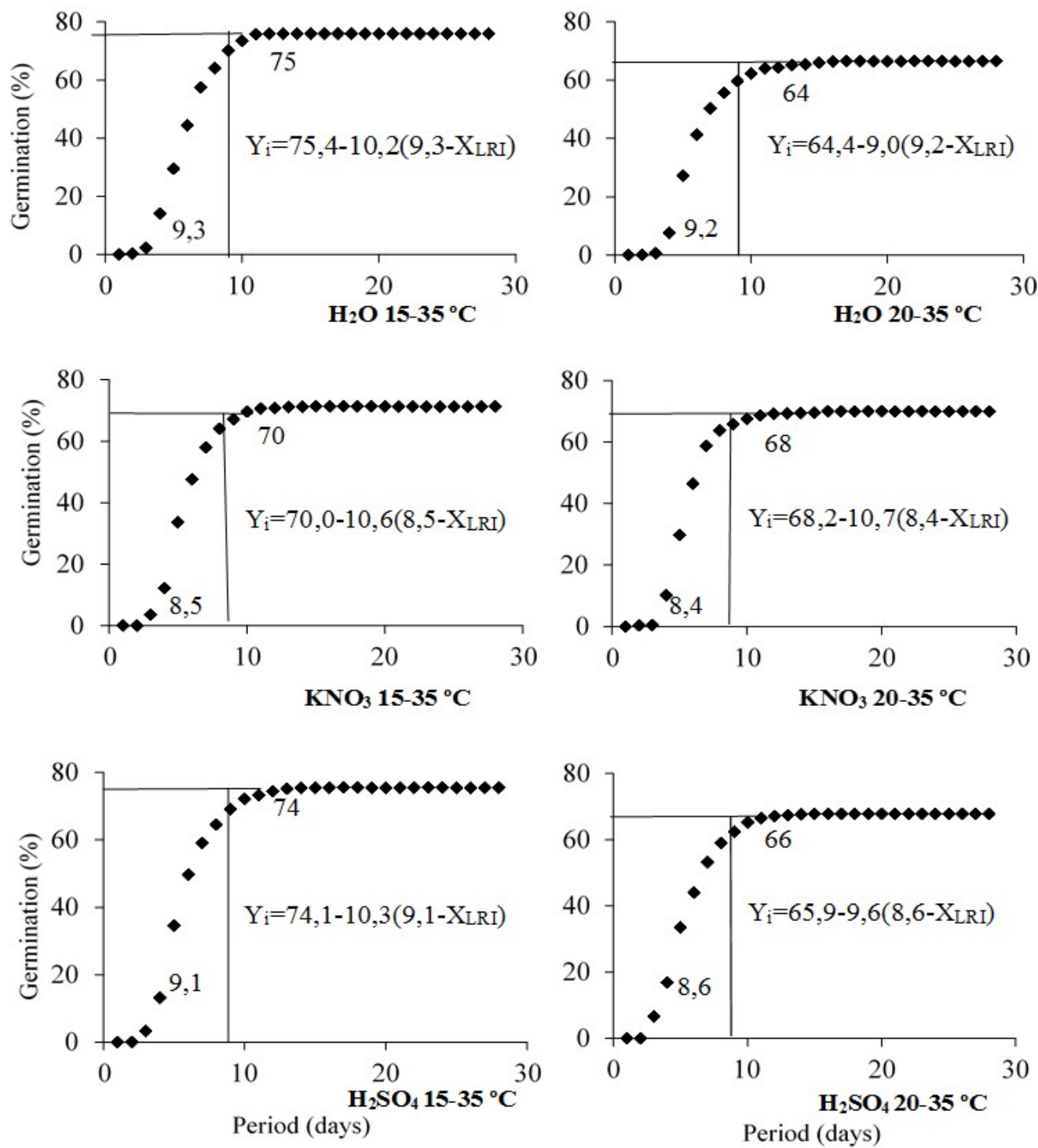
The period of 21 days for the conduction of the germination test of $B$. humidicola, as established by the national and international Rules for Testing Seeds, may be considered a long one since the present work showed that the stabilization of the germination period is verified to occur between 8.4 and 9.3 days (Figure 1). So, considering that the number of days for the germination test final count should be expressed as a round number (BRASIL, 2009; ISTA, 2009), it is suggested that the number of days for the final count of the germination test of $B$. humidicola seeds is 10 days after sowing independently of the application of methods for overcoming dormancy and temperature conditions.

Gaspar-Oliveira et al. (2008), working with $B$. brizantha, and Tomaz et al. (2015) with $B$. decumbens seeds, report results indicating that the standard germination tests of those species may be reduced to periods, respectively, of 11 and 12 days.

The fact that the stabilization of germination occurred at approximately half the period recommended by the Rules for Testing Seeds, would have positive implications from the economical point-of-view since it would mean a reduction in the time necessary for the evaluation of seed germination in seed laboratories and the taking of decisions by producing companies.

\section{Conclusion}

The standard germination test of $B$. humidicola seed may be conducted under conditions of 15 $35{ }^{\circ} \mathrm{C}$, without treatments for breaking dormancy, with the final count being made 10 days after seed sowing.

\section{References}

BRASIL. Ministério da Agricultura, Pecuária e Abastecimento Gabinete do Ministro. Instrução Normativa $\mathrm{n}^{\circ} 30$, de 21 de maio de 2008. Normas e padrões para produção e comercialização de sementes de espécies forrageiras de clima tropical. Diário Oficial da União, Poder Executivo, Brasília, 23 maio 2008, Seção 1, p. 1-13.

Ministério da Agricultura, Pecuária e Abastecimento. Regras para análise de sementes. Secretaria de Defesa Agropecuária. Brasília: MAPA/ ACS, 2009. 395 p.

Ministério da Agricultura. Regras para análise de sementes. Departamento Nacional de Produção Vegetal. Brasília: MA/DNPV/DISEN, 1980. 188 p.

BRITES, F. H. R.; SILVA JUNIOR, C. A.; TORRES, F. E. Germinação de semente comum, escarificada e revestida de diferentes espécies forrageiras tropicais. Bioscience Journal, Uberlândia, v. 27, n. 4, p. 629-634, 2011.

CARNEIRO, J. W. P.; ROSSETO, M. Z.; GIOVANI, R. Influência da posição da semente no substrato e da temperatura de germinação no desempenho de dois lotes de sementes de Brachiaria humidicola. Revista Brasileira de Sementes, Londrina, v. 8, n. 3, p. 41-46, 1986.

CAVALCANTE FILHO, F. N.; USBERTI, R. Thermal and moisture content effects on storability and seed dormancy releasing on Brachiaria brizantha cultivars. Revista Brasileira de Sementes, Londrina, v. 30, n. 3, p. 95-103, 2008.

COSTA, C. J.; ARAUJO, R. B.; VILLAS BOAS, H. D. C. Tratamentos para a superação de dormência em sementes de Brachiaria humidicola (Rendle) Schweick. Pesquisa Agropecuária Tropical, Goiânia, v. 41, n. 4, p. 519-524, 2011.

GASPAR-OLIVEIRA, C. M.; MARTINS, C. C.; NAKAGAWA, J.; CAVARIANI, C. Duração do teste de germinação de Brachiaria brizantha cv. marandu (Hochst. ex A. Rich.) Stapf. Revista Brasileira de Sementes, Londrina, v. 30, n. 3, p. 30-38, 2008.

GASPAR-OLIVEIRA, C. M.; MARTINS, C. C.; NAKAGAWA, J.; TOMAZ, C. D. A. Manutenção da umidade do substrato durante o teste de germinação de Brachiaria brizantha. Revista Brasileira de Sementes, Londrina, v. 29, n. 3, p. 52-60, 2007.

INTERNATIONAL SEED TESTING ASSOCIATION ISTA. International rules for seed testing. In: Chapter 5: The Germination Test. Bassesrdorf: ISTA, 2009. 29 p.

. International rules for seed testing. Seed Science and Technology, Zürich, v. 13, n. 2, p. 299-355, 1985.

MARCOS FILHO, J. Fisiologia de sementes de plantas cultivadas. Piracicaba: Fealq, 2005. 495 p. 
MARTINS, C. C.; BOMBONATO, J.; MARTINS, D.; MARCUSSI, F. Effects of substratum, temperature, and treatments to overcome dormancy on the germination of Fimbristylis dichotoma seeds. Revista de Ciências Agrárias, Belém, v. 56, p. 44-48, 2013. Suplemento 1.

MARTINS, C. C.; MARTINS, D. Superação da dormência de sementes de gramíneas. In: SILVA, J. F.; MARTINS, D. (Ed.). Manual de aulas práticas de plantas daninhas. Jaboticabal: Funep, 2013. cap. 8, p. 45-56.

NOVEMBRE, A. D. L. C.; CHAMMA, H. M. C. P.; GOMES, R. B. R. Viabilidade das sementes de braquiária pelo teste de tetrazólio. Revista Brasileira de Sementes, Londrina, v. 28, n. 2, p. 147-151, 2006.

OLIVEIRA, P. R. P.; MASTROCOLA, M. A. Longevidade das sementes de gramíneas forrageiras tropicais. Boletim Indústria Animal, Nova Odessa, v. 41, n. 1, p. 203-211, 1984.
SALLUM NETO, F.; CARVALHO, L. R.; MISCHAN, M. M. Ajustes de modelos não lineares a dados de crescimento com estrutura de erros independentes e autoregressivos de primeira ordem-aplicações. Revista Brasileira de Biometria, São Paulo, v. 31, n. 4, p. 631644, 2013.

TOMAZ, C. A.; MARTINS, C. C.; SANCHES, M. F. G.; VIEIRA, R. D. Time reduction for surinam grass seed germination test. Ciência e Agrotecnologia, Lavras, v. 39, n. 5, p. 488-497, 2015.-

USBERTI, R.; MARTINS, L. Sulphuric acid scarification effects on Brachiaria brizantha, B. humidicola and Panicum maximum seed dormancy release. Revista Brasileira de Sementes, Londrina, v. 29, n. 2, p. 143-147, 2007.

VERZIGNASSI, J. R. A pesquisa em sementes de espécies forrageiras de clima tropical no Brasil. Informativo ABRATES, Londrina, v. 23, n. 2, p. 36-37, 2013. 